\title{
Percepatan Penyediaan Benih Sumber Kedelai Unggul Secara In Vitro
}

\author{
Erni Suminar ${ }^{*}$, Sumadi ${ }^{1}$, Syariful Mubarok ${ }^{1}$, Toto Sunarto ${ }^{2}$, dan Nita Suswati Endah Rini ${ }^{3}$ \\ ${ }^{1}$ Staf Departemen Budidaya Pertanian FapertaUnpad \\ ${ }^{2}$ Staf Departemen Hama \& Penyakit Tumbuhan \\ ${ }^{3}$ Alumni Prodi Agroteknologi Minat Teknologi Benih Faperta Unpad \\ Alamat korespondensi: erni.suminar@unpad.ac.id
}

\begin{abstract}
In vitro method to fasten availability high quality soybean seeds
\end{abstract}

Soybean is an important crop as a source of food and its demand has increased every year. Several new varieties of soybean have been generated, but the number is still limited. Furthermore, the infestation of pests and infection of diseases have also limited the new soybean varieties production as it increase the risk of growth failure. Therefore, methods to fasten the availability of high quality of soybean seeds need to be developed. One of which can be done through in vitro culture method. The objective of this study was to obtain the best type and the best concentration of cytokinin for the growth of soybean explants in vitro. The experiment was conducted in Seed Technology and Tissue Technology Laboratory, Faculty of Agriculture, Universitas Padjadjaran. The experimental design used was Completely Randomized Design with 13 treatments and four replications. The basic media used were Murashige and Skoog (MS) + Vitamin B5 with addition of BAP (1.0 mg/l, $1.5 \mathrm{mg} / 1$, and $2.0 \mathrm{mg} / \mathrm{l})$, Kinetin $(0.5 \mathrm{mg} / 1,1.0 \mathrm{mg} / \mathrm{l}$, and $1.5 \mathrm{mg} / \mathrm{l})$, TDZ (0.01 mg/l, $0.1 \mathrm{mg} / \mathrm{l}$, and $1.0 \mathrm{mg} / \mathrm{l})$, and coconut water (10\%, 15\%, and 20\%). The result showed that cytokinin types and concentrations gave different effect to soybean explant growth. The best treatment was demonstrated by BAP at the concentration of $1.5 \mathrm{mg} / \mathrm{l}$ as shown by the highest percentage of leaves and the number of shoots. However, it did not affect the percentage of buds produced by explant and the percentage of callus produced by explant.

Keyword : BAP, Kinetin, TDZ, Coconut water, Soybean.

\begin{abstract}
Abstrak
Kedelai merupakan komoditas yang memegang peranan penting. Permintaan akan kedelai meningkat setiap tahunnya. Varietas kedelai baru yang bersifat unggul sudah banyak dihasilkan, namun jumlahnya masih terbatas. Tingginya serangan hama dan penyakit saat perbanyakkan benih di lapangan menyebabkan tingginya resiko kegagalan dalam pertumbuhan varietas baru tersebut. Sehingga perlu dilakukan percepatan penyediaan benih sumber varietas unggul di laboratorium secara in vitro. Tujuan penelitian ini adalah untuk mendapatkan jenis dan konsentrasi sitokinin yang terbaik untuk pertumbuhan eksplan kedelai in vitro. Penelitian dilakukan di Laboratorium Kultur Jaringan Teknologi Benih Fakultas Pertanian Universitas Padjadjaran. Rancangan percobaan yang digunakan adalah Rancangan Acak Lengkap dengan tiga belas perlakuan dan empat ulangan. Media dasar yang digunakan adalah Murashige dan Skoog $(\mathrm{MS})+$ Vitamin B5 dengan penambahan BAP $(1,0 \mathrm{mg} / \mathrm{l} ; 1,5 \mathrm{mg} / \mathrm{l} ; 2,0 \mathrm{mg} / \mathrm{l})$, Kinetin $(0,5 \mathrm{mg} / \mathrm{l} ; 1,0$ $\mathrm{mg} / \mathrm{l} ; 1,5 \mathrm{mg} / \mathrm{l})$, TDZ (0,01 mg/l; $0,1 \mathrm{mg} / 1 ; 1,0 \mathrm{mg} / \mathrm{l})$, dan air kelapa (10\%; 15\%; 20\%). Hasil percobaan menunjukkan bahwa pemberian jenis dan konsentrasi sitokinin memberikan pengaruh yang berbeda terhadap pertumbuhan eksplan. Perlakuan terbaik diperoleh pada BAP dengan
\end{abstract}


konsentrasi $1,5 \mathrm{mg} / \mathrm{l}$ yang ditunjukkan dengan tingginya persentase jumlah daun dan tunas yang terbentuk. Akan tetapi, penambahan sitokinin tersebut tidak memberikan pengaruh terhadap persentase eksplan dalam membentuk tunas dan persentase eksplan dalam membentuk kalus.

Kata Kunci : BAP, Kinetin, TDZ, Air Kelapa, Kedelai

\section{PENDAHULUAN}

Kedelai merupakan komoditas tanaman pangan yang memiliki nilai penting ketiga di Indonesia setelah padi dan jagung. Kebutuhan kedelai mengalami peningkatan setiap tahunnya seiring dengan peningkatan jumlah penduduk di Indonesia. BPS (2013) melaporkan produksi kedelai di Indonesia pada tahun 2012 sebanyak 843,15 ribu ton biji kering, menurun sebanyak 8,13 ribu ton $(0,96 \%)$ dari tahun 2011, sedangkan kebutuhan untuk konsumsi di Indonesia pada tahun yang sama adalah sebesar 2,283 juta ton atau defisit sekitar 1,5 juta ton. Kekurangan kedelai ini kemudian dipenuhi melalui kebijakan impor. Penurunan produksi kedelai di Indonesia dipengaruhi oleh beberapa faktor, diantaranya luas areal panen yang terus menurun serta serangan hama dan penyakit tanaman (Harsono, 2008). Serangan hama dan penyakit tanaman kedelai seperti penyakit karat daun, dapat menurunkan produksi kedelai sebesar $10 \%-90 \%$ (Sumartini, 2010). Penggunaan varietas unggul tahan hama penyakit merupakan salah satu solusi yang bisa digunakan untuk menangani permasalahan tersebut.

Faktor lain yang menyebabkan rendahnya produksi kedelai di Indonesia adalah ketersediaan benih unggul yang masih terbatas (Purwantoro, 2012). Benih merupakan salah satu faktor penentu produktivitas kedelai di Indonesia hingga 28\% selain pupuk dan serangan hama penyakit (Suherman, 2013). Purwantoro (2012) menyatakan bahwa penggunaan benih unggul dapat menentukan tingkat keberhasilan atau kegagalan hasil panen hingga 60\%. Wahyudi dkk. (2012) menyebutkan bahwa kedelai var. Mutiara 1 merupakan varietas kedelai hasil iradiasi sinar gama yang dirilis pada tahun 2010 oleh Badan Tenaga Nuklir (BATAN), yang bersifat tahan terhadap penyakit karat daun (Phakopsora pachirhyzi Syd), tahan terhadap penyakit bercak/hawar daun coklat (Cercospora) dan agak rentan CMMV (Cowpea Mild Mottle Virus) serta tahan terhadap hama penggerek pucuk (Melanagromyza sojae).

Kedelai var. Mutiara 1 ini merupakan kedelai biji besar yang sangat cocok digunakan sebagai bahan baku dalam industri pembuatan tempe dan tahu (Dinas Pertanian Tanaman Pangan Provinsi Jawa Barat, 2012). Kendala lapangan yang menjadi salah satu faktor yang mempengaruhi produksi benih kedelai di Indonesia adalah faktor lingkungan diantaranya lama penyinaran atau panjang hari. Menurut Adisarwanto (2008), tanaman kedelai merupakan tanaman subtropis yang sangat peka terhadap lama penyinaran sinar matahari, dengan panjang hari yang lebih lama $(14-16$ jam/hari) jika dibandingkan dengan wilayah tropis (11 - 12 jam/hari). Lama penyinaran tersebut berpengaruh terhadap kecepatan berbunga, pertumbuhan tanaman, dan jumlah polong, sehingga menyebabkan produksi benih kedelai masih rendah. Produksi benih sumber tidak bisa dilakukan sepanjang tahun, karena terkendala oleh musim yang tidak sesuai untuk budidaya kedelai. Salah satu alternatif yang dapat dilakukan adalah dengan melalui upaya percepatan penyediaan benih sumber bermutu melalui perbanyakan secara kultur in vitro.

Media MS + vitamin B5 (MSB5) merupakan media dasar MS dengan penambahan vitamin yang berasal dari media B5. Kelebihan media MSB5 jika dibandingkan dengan media MS, adalah vitamin yang digunakan berasal dari media B5 yang lebih mendukung untuk pertumbuhan kedelai, diantaranya adalah konsentrasi thiamine yang digunakan lebih besar yaitu $10 \mathrm{mg} / \mathrm{l}$ jika dibandingkan pada media MS yaitu sebesar $0,1 \mathrm{mg} / \mathrm{l}$, konsentrasi nicotinic acid dan piridoxyn $\mathrm{HCl}$ juga lebih besar yaitu $1,0 \mathrm{mg} / \mathrm{l}$ jika dibandingkan pada media MS yaitu sebesar 0,5 mg/l.

Penggunaan zat pengatur tumbuh di dalam kultur jaringan tergantung pada tujuan atau arah pertumbuhan tanaman yang dikehendaki. Sitokinin merupakan golongan ZPT yang mendorong pembelahan sel (Wattimena, 1988). Beberapa jenis sitokinin yang biasa digunakan dalam memicu regenerasi eksplan adalah BAP (Benzylaminopurine), Kinetin, dan Thidiazuron (TDZ), selain itu bahan organik yang dapat dijadikan sebagai sitokinin dalam kultur jaringan adalah air kelapa, banyak mengandung senyawa organik komplek dan terkandung difenilurea memiliki aktivitas sama seperti sitokinin yang berfungsi untuk memacu multiplikasi tunas (Pierik, 1997;Wattimena, 
1988). Semakin tinggi kecepatan multiplikasi tunas maka semakin banyak pula tunas yang terbentuk, sehingga jumlah bibit tanaman yang dihasilkan lebih banyak dalam waktu yang lebih cepat.

Beberapa sitokinin yang sudah digunakan dalam kultur in vitro tanaman diantaranya TDZ, BAP, dan Kinetin. Lu (1993) menyatakan TDZ merupakan salah satu sitokinin yang dapat meningkatkan kemampuan multiplikasi tunas, menginduksi pembentukan tunas adventif dan proliferasi tunas aksilar. Peggunaan TDZ pada konsentrasi rendah (0,0022 sampai 0,088 mg/l) sangat efektif dipergunakan dalam mikropropagasi tanaman. Hutchinson et al. (2010) melaporkan bahwa penggunaan TDZ pada konsentrasi $1,0 \mathrm{mg} / 1$ memberikan hasil yang baik pada pembentukan tunas dan panjang tunas pada tanaman Alstroemeria aurantiaca (Peruvian Lily). Penggunaan TDZ pada konsentrasi rendah $(0,1 \mathrm{mg} / \mathrm{l})$ tidak memberikan efek yang signifikan, sedangkan pemberian TDZ pada konsentrasi tinggi (5,0 mg/l) bersifat sebagai inhibitor. Kaneda et al. (1997) melaporkan bahwa penggunaan TDZ 1,0 mg/l memberikan hasil yang paling baik pada pembentukan tunas pada tanaman kedelai dari eksplan hipokotil.

BAP merupakan sitokinin yang aktif dan daya rangsangnya lebih lama, karena tidak mudah dirombak oleh enzim di dalam tanaman (George \& Sherington, 1984). Penggunaan BAP dengan konsentrasi 1,5 mg/l menunjukkan frekuensi regenerasi tunas paling tinggi diantara 5 konsentrasi yang lain $(0,5 \mathrm{mg} / 1 ; 1,0 \mathrm{mg} / \mathrm{l} ; 2,0 \mathrm{mg} / 1 ; 2,5 \mathrm{mg} / 1 ; 3,0$ $\mathrm{mg} / \mathrm{l})$ pada kultur in vitro kedelai varietas Cuban Incasoy-36 pada media MSB5 (Soto et al., 2013), BAP dengan konsentrasi $1,0 \mathrm{mg} / 1$ memberikan hasil yang paling baik jika dibandingkan konsentrasi lainnya $(2,0 \mathrm{mg} / \mathrm{l})$ terhadap pembentukan pucuk pada kultur in vitro kedelai kultivar NARC-4 dan NARC-7 (Zia et al., 2010), BAP 2,0 mg/1 + 0,5 mg/1 pada media MS memberikan hasil yang terbaik ada pembentukan tunas pucuk tanaman kacang arab atau kacang chickpea (Cicer arietinum L.) (Huda et al., 2003).

Kinetin merupakan jenis sitokinin yang dapat meningkatkan pembelahan sel pada jaringan tanaman, mengatur perkembangan dan pertumbuhan tanaman (Wetherell 1982). Hesar et al. (2011) melaporkan bahwa penggunaan kinetin pada tanaman Matthiola incana (Virginia Stock) pada konsentrasi $2 \mathrm{mg} / \mathrm{l}$ memberikan hasil terbaik pada jumlah tunas yang terbentuk dan konsentrasi 1 $\mathrm{mg} / \mathrm{l}$ memberikan hasil terbaik pada panjang akar. Xiao dan Tian (2008) melaporkan bahwa penambahan kinetin 0,5 mg/l pada media MSB5 memberikan hasil yang terbaik pada pembentukan tunas tanaman kedelai kultivar Jilin 35, Dongnong 42, Hefeng 25 dan Hefeng 41.

Kristina \& Syahid (2012) melaporkan bahwa penggunaan air kelapa pada perbanyakan in vitro tanaman temulawak dengan konsentrasi 15\% memberikan hasil terbaik dalam merangsang pertumbuhan tunas in vitro. Nasib et al. (2008) melaporkan bahwa penggunaan air kelapa pada perbanyakan in vitro tanaman kiwi dengan kosentrasi air kelapa 20\% + BAP 2 mg/l pada media dasar MS memberikan hasil terbaik pada panjang akar, jumlah tunas, dan jumlah pucuk. Amutha et al. (2003) menyatakan bahwa penambahan NAA $(1,07$ $\mu \mathrm{M})$, BA $(8,8 \mu \mathrm{M})$ dan air kelapa $10 \%$ pada media MS memberikan hasil terbaik pada pembentukan tunas adventif tanaman kacang hijau (Vigna radiata) kv. KM2, CO3, dan Pusa Vishal.

\section{BAHAN DAN METODE}

$\begin{array}{cccc}\text { Percobaan } & \text { dilakukan di Laboratorium } \\ \text { Kultur Jaringan } & \text { Teknologi } & \text { Benih, Fakultas }\end{array}$ Pertanian, Universitas Padjadjaran Jatinangor, Sumedang, pada bulan Februari sampai Mei 2014. Bahan tanam dalam percobaan ini berupa eksplan embryonic axis benih kedelai var. Mutiara 1 yang diperoleh dari Badan Tenaga Nuklir Nasional (BATAN) Jakarta, sedangkan media dasar yang digunakan adalah media Murashige and Skoog (MS) + vitamin B5 dengan penambahan ZPT BAP (1,0 $\mathrm{mg} / \mathrm{l} ; 1,5 \mathrm{mg} / \mathrm{l} ; 2,0 \mathrm{mg} / \mathrm{l})$, Kinetin $(0,5 \mathrm{mg} / 1 ; 1,0 \mathrm{mg} / \mathrm{l}$; 1,5 mg/l), TDZ (0,01 mg/l;0,1 mg/l; 1,0 mg/l) dan siokinin alami yaitu air kelapa (10\%; 15\%; 20\%). Air kelapa yang dipergunakan merupakan air kelapa hijau dengan tingkat kematangan sedang. Bahanbahan lain yang dipergunakan dalam percobaan ini adalah agar-agar, gula pasir, aquades, alkhohol 95\%, alkhohol 70\%, larutan $\mathrm{NaOHCl}$, tissue, spiritus, detergent anti bakteri, $\mathrm{HCl}, \mathrm{NaOH}$, dan kertas label.

Percobaan ini mengguakan Rancangan Acak Lengkap (RAL) dengan 13 perlakuan jenis dan konsentrasi sitokinin. Tiap perlakuan diulang sebanyak empat kali, masing-masing ulangan terdiri atas empat unit, sehingga totalnya adalah 208 unit. Perlakuan yang dipergunakan dalam percobaan ini adalah sebagai berikut: A (Tanpa ZPT (Kontrol); B (BAP 1,0 mg/l); C (BAP 1,5 mg/l); D (BAP 2,0 mg/l); $\mathrm{E}$ (Kinetin 0,5 mg/l); F (Kinetin 1,0 mg/l); G (Kinetin 1,5 mg/l); H (TDZ 0,01 mg/l); I (TDZ 0,1 mg/l); J (TDZ 1,0 mg/l); K (Air Kelapa 10\%); L (Air Kelapa 15\%); M (Air Kelapa 20\%). 
Data yang diperoleh di uji dengan menggunakan uji $F$ (Fisher). Apabila terdapat perbedaan yang nyata antar perlakuan dilakukan uji lanjut dengan uji perbedaan nilai rata-rata dengan Uji Scott Knot pada taraf 5\%.

\section{HASIL DAN PEMBAHASAN}

\section{Persentase Eksplan Membentuk Daun}

Daun merupakan komponen utama suatu tumbuhan untuk melaksanakan proses fotosintesis.
Semakin banyak jumlah daun yang terdapat pada suatu tanaman maka proses fotosintesis yang terjadi juga lebih tinggi, sehingga fotosintat yang dihasilkan juga lebih banyak (Pertamawati, 2010). Hasil pengamatan menunjukkan bahwa media perlakuan mampu menstimulasi proses regenerasi eksplan menjadi daun (Gambar 1.). Proses regenerasi ini terjadi karena media yang digunakan mengandung nutrisi makro, nutrisi mikro, ZPT, serta vitamin yang sesuai dalam memicu terjadinya regenerasi pada eksplan kedelai yang ditanam.

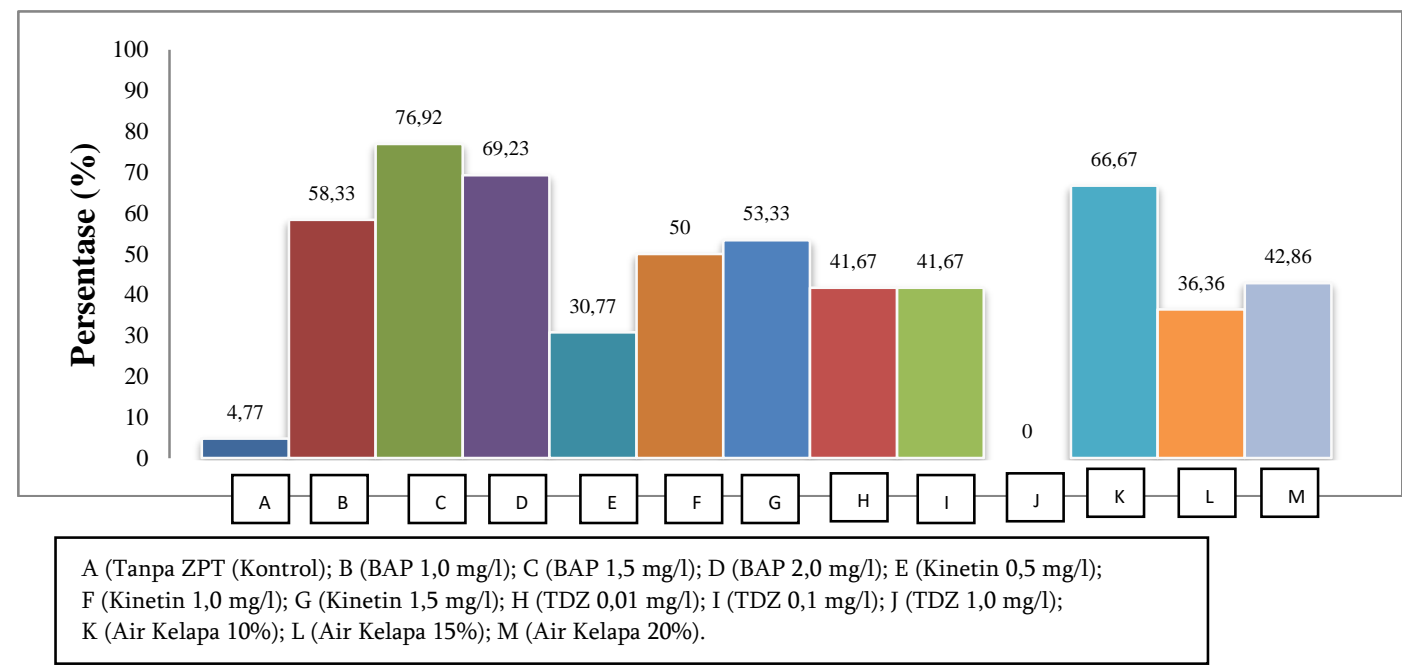

Gambar 1. Data persentase eksplan membentuk daun.

Proses pembentukan organ yang terjadi melalui proses organogenesis langsung dan tidak langsung. Organogenesis langsung ditandai dengan eksplan yang ditanam langsung beregenerasi membentuk tunas dan daun setelah eksplan tersebut ditanam. Organogenesis tidak langsung ditandai dengan pembentukan organ-organ tanaman seperti tunas, daun, akar terjadi setelah eksplan beregenerasi menjadi kalus. Organogenesis tidak langsung yang terjadi pada percobaan ini dapat dilihat pada Gambar 1. Tahap organogenesis tidak langsung pada percobaan ini dimulai dengan pembentukan kalus yang kemudian disusul dengan organ-organ tanaman yang lainnya. Proses organogenesis dan morfogenesis dalam kultur jaringan sangat dipengaruhi oleh keberadaan zat pengatur tumbuh (ZPT) pada media. Zat pengatur tumbuh pada kultur jaringan berperan penting dalam mengontrol proses morfogenesis pada ekplan tanaman (Lestari, 2011; Dafalla et al., 2011). Beberapa ZPT memberikan pengaruh yang berbedabeda terhadap prose organogenesis dan morfogenesis eksplan. ZPT auksin dan sitokinin berperan dalam pembentukan kalus, pembentukan akar, pembentukan tunas, proliferasi tunas, dan proliferasi kalus (Lubaina \& Murugan, 2012; Parabia et al., 2007).

\section{Persentase Eksplan Membentuk Kalus}

Pembentukan kalus dalam kultur in vitro memungkinkan untuk terbentuknya tunas-tunas dari sel-sel baru yang terdapat pada kalus dan dapat membentuk tanaman baru. Hasil pengamatan terhadap persentase eksplan membentuk kalus menunjukkan bahwa eksplan embrionic axis kedelai yang digunakan mampu membentuk kalus. Terbentuknya kalus pada kultur in vitro menunjukkan adanya proses organogenesis tidak langsung pada kultur. Terbentuknya kalus pada kultur in vitro tanaman bergantung pada keseimbangan ZPT yang terkandung didalam eksplan serta jenis eksplan dan spesies tanaman yang digunakan (Da Silva et al., 2003; Rao et al., 2005). 
Kombinasi antara auksin dan sitokinin dengan konsentrasi auksin yang lebih tinggi dari pada auksin memberikan hasil yang baik terhadap pembentukan kalus pada kultur in vitro (Rao et al., 2005).

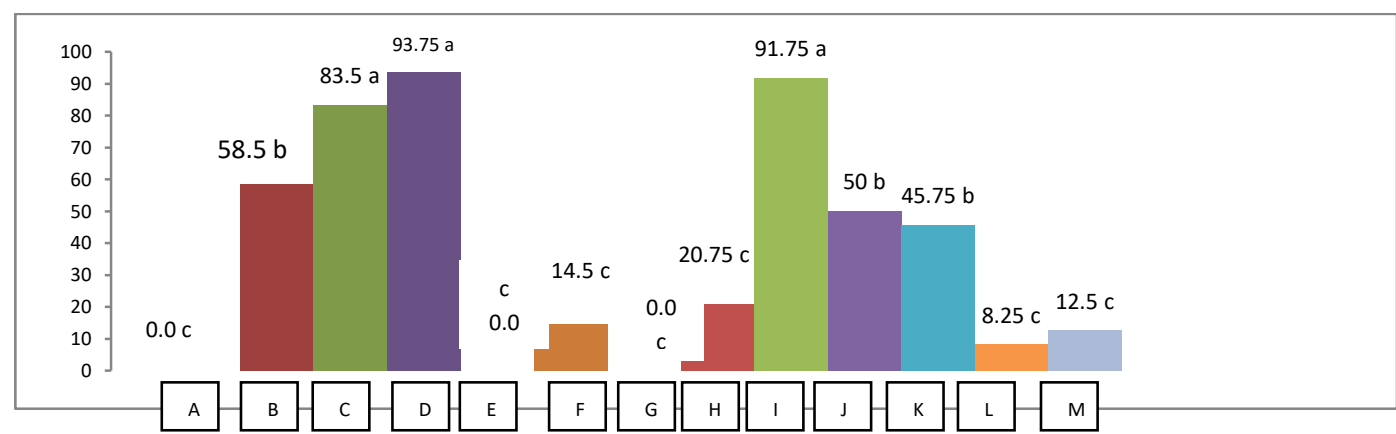

$$
\begin{aligned}
& \text { A (Tanpa ZPT (Kontrol); B (BAP 1,0 } \left.\mathrm{mg} \mathrm{L}^{-1} \text { ); C (BAP 1,5 mg L-1); D (BAP 2,0 } \mathrm{mg} \mathrm{L}^{-1}\right) ; \mathrm{E} \text { (Kinetin 0,5 } \mathrm{mg} \mathrm{L}^{-1} \text { ); } \\
& \text { F (Kinetin 1,0 } \left.\left.\left.\mathrm{mg} \mathrm{L}^{-1}\right) ; \mathrm{G} \text { (Kinetin 1,5 } \mathrm{mg} \mathrm{L}^{-1}\right) ; \mathrm{H} \text { (TDZ 0,01 } \mathrm{mg} \mathrm{L}^{-1}\right) ; \mathrm{I} \text { (TDZ 0,1 } \mathrm{mg} \mathrm{L}^{-1} \text { ); J (TDZ 1,0 } \mathrm{mg} \mathrm{L}^{-1} \text { ); } \\
& \text { K (Air Kelapa 10\%); L (Air Kelapa 15\%); M (Air Kelapa 20\%). }
\end{aligned}
$$

Gambar 2. Data Persentase eksplan membentuk kalus (\%).

Hasil percobaan menunjukkan persentase eksplan membentuk kalus mencapai $93,75 \%$ pada 12 MST (Gambar 2). Persentase eksplan membentuk kalus menunjukkan nilai yang tidak berbeda nyata pada perlakuan C (BAP 1,5 mg/l), D(BAP 2,0 mg/l) dan perlakuan I (TDZ $0,1 \mathrm{mg} / \mathrm{l}$ ) dengan persentase yang relatif lebih tinggi bila dibandingkan dengan perlakuan-perlakuan yang lain. Penggunaan media B5 yang mengandung sitokinin memberikan hasil yang terbaik terhadap pembentukan kalus pada kedelai kultivar CO3. Penelitian lain juga melaporkan penambahan BAP pada media MSB5 $\begin{array}{lllll}\text { dengan kisaran konsentrasi } & 2,0 & -5,0 & \mathrm{mg} / \mathrm{l}\end{array}$ memberikan hasil yang terbaik terhadap pembentukan kalus eksplan embrionic axis kedelai kultivar CO3, sedangkan pada konsentrasi yang lebih rendah dan lebih tinggi menurunkan persentase kalus yang terbentuk (Radhakrisnan \& Ranjithakumari, 2007). Pembentukan kalus dapat dilihat pada Gambar 3.
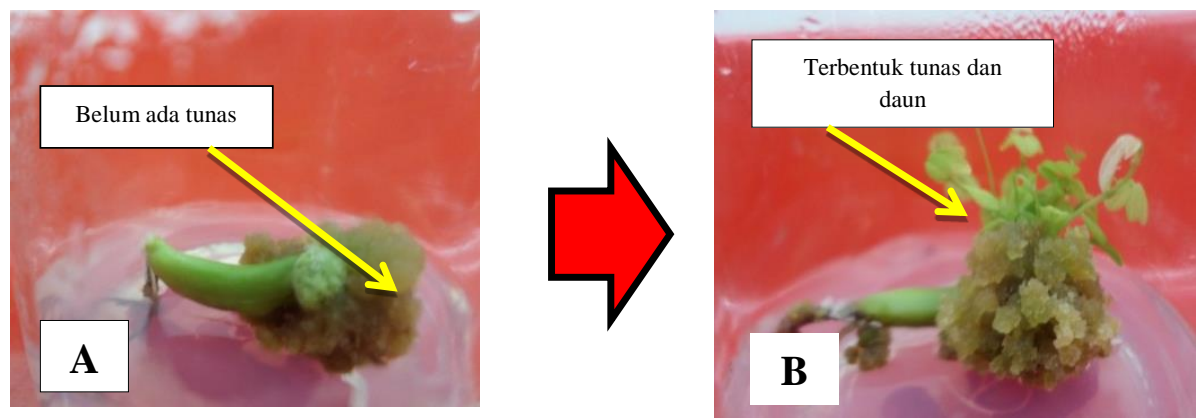

Gambar 3. Tahapan pembentukan daun dan tunas melalui organogenesis tidak langsung. A. Kalus berakar; B. Kalus berakar tumbuh menjadi tunas dan daun.

Penambahan sitokinin dalam media kultur dapat mempengaruhi konsentrasi hormon endogen yang terkandung dalam suatu kultur. Tingginya persentase kalus pada perlakuan C (BAP $1,5 \mathrm{mg} / \mathrm{l}$ ), D (BAP 2,0 mg/l) dan I (TDZ 0,1 mg/l) diduga karena interaksi antara hormon endogen dan eksogen yang ditambahkan mengarah kepada pertumbuhan kalus, diduga konsentrasi auksin dalam kultur lebih tinggi bila dibandingkan dengan kandungan sitokininnya. Apabila konsentrasi auksin 
yang terkandung dalam suatu eksplan lebih tinggi daripada kandungan sitokininnnya maka arah pertumbuhan eksplan adalah membentuk kalus.

\section{Jumlah Tunas per Eksplan}

Terbentuknya tunas dalam kultur in vitro sangat menentukan keberhasilan produksi bibit yang banyak, seragam, dan dalam waktu yang relatif singkat. Semakin banyak tunas yang terbentuk, maka bibit yang dihasilkan melalui kultur jaringan juga semakin banyak. Multiplikasi tunas dalam kultur in vitro dapat dipacu dengan menambahkan ZPT berupa sitokinin dalam media yang digunakan. Konsentrasi sitokinin yang relatif tinggi daripada auksin dapat merangsang inisiasi tunas, sebaliknya konsentrasi auksin yang relatif tinggi daripada sitokinin dapat merangsang inisiasi akar atau kalus. Data hasil analisis ragam menunjukkan bahwa penambahan sitokinin pada media dasar MSB5 memberikan pengaruh yang berbeda nyata terhadap jumlah tunas pada 12 MST.

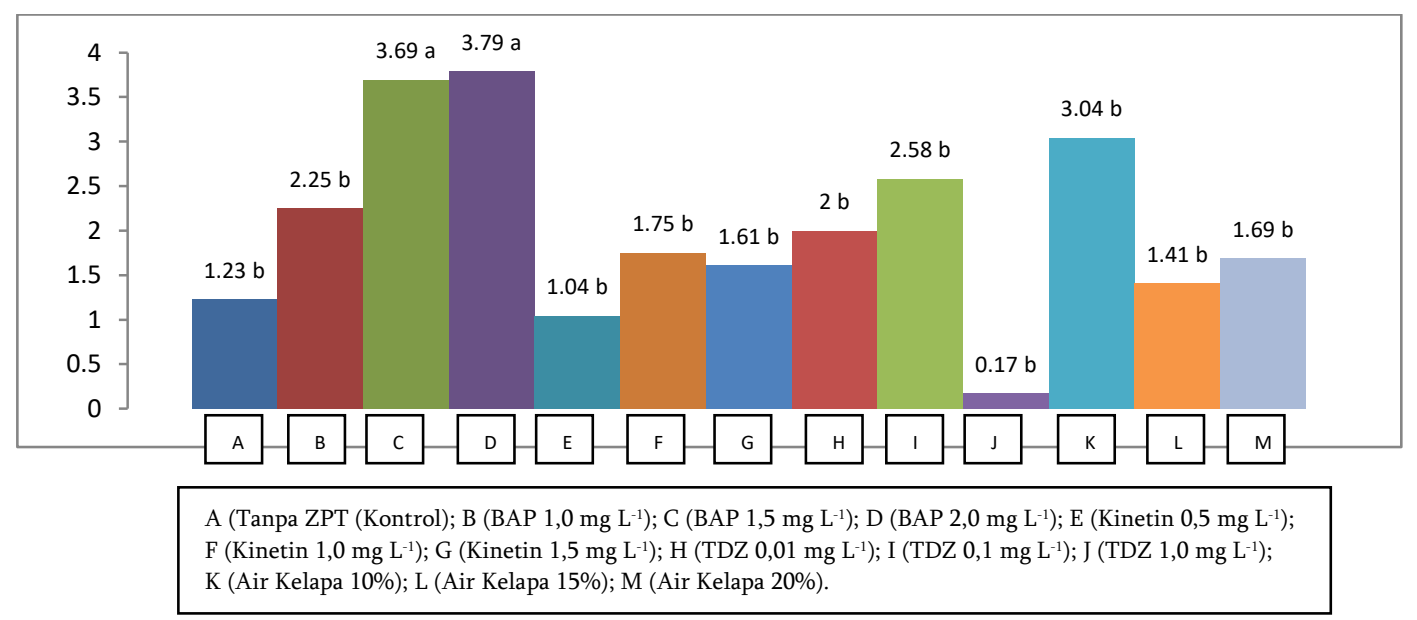

Gambar 4. Data jumlah tunas per eksplan 12 MST.

Pada 12 MST perlakuan yang menghasilkan jumlah tunas yang relatif tinggi terdapat pada perlakuan C (BAP 1,5 mg/l) dan D (BAP 2,0 mg/l). Berdasarkan uji lanjut yang dilakukan, perlakuanperlakuan tersebut menunjukkan nilai yang tidak berbeda nyata antar perlakuan (Gambar 4.). BAP dan TDZ merupakan jenis sitokinin yang mampu merangsang pembentukan tunas pada kultur in vitro tanaman, sehingga penambahan sitokinin pada media dengan konsentrasi tertentu mampu meningkat multiplikasi tunas pada kultur in vitro tanaman. Gunawan (1988) menyatakan bahwa penggunaan BAP dengan konsentrasi tinggi dan masa yang panjang dapat mempengaruhi jumlah dan bentuk tunas. BAP merupakan salah satu jenis sitokinin yang memiliki sifat sangat aktif yang berperan dalam diferensiasi sel, memacu pertumbuhan tunas, proliferasi tunas ketiak dan penghambat pembentukkan akar (Wattimena, 1988). BAP telah banyak digunakan dalam kultur in vitro padaberbagai jenis spesies tanaman dan terbukti mampu meningkatkan multiplikasi tunas (Supriati dkk., 2006). Sitokinin memegang peranan dalam perkembangan tanaman terutama dalam pembentukan dan multiplikasi tunas serta merangsang pembelahan dan pembesaran sel (Mok \& Mok 2001).

TDZ merupakan jenis sitokinin sintetis yang digunakan dalam merangsang regenerasi pada berbagai spesies tanaman, dengan tingkat keefektivan mencapai 10 hingga 1000 kali lipat bila dibandingkan dengan hormon lainnya (Guo et al., 2011). Penggunaan TDZ dapat merangsang pembentukan tunas lebih baik dari pada BA (Kaneda et al., 1996). Penggunaan TDZ pada konsentrasi rendah dapat memicu pembentukan tunas pada kultur in vitro tanaman. TDZ sangat berperan dalam merangsang morfogeneis pada kultur in vitro tanaman, dengan beberapa respon seperti mampu menginduksi terbentuknya kalus dari berbagai macam sumber eksplan dan spesies tanaman, mempersingkat waktu dalam regenerasi kultur, dan meningkatkan jumlah tunas per eksplan (Sculze, 2007). TDZ pada konsentrasi lebih tinggi (1-2 mg/l) merangsang pembentukan tunas terbaik pada eksplan hipokotil tanaman kedelai (Kaneda et al., 1996). TDZ dengan kosentrasi yang lebih rendah (0,05 mg/l) dikombinasikan dengan BA $0,1 \mathrm{mg} / 1$ 
memberikan hasil terbaik dalam jumlah tunas yang dihasilkan pada tanaman Encok (Plumbago zeylanica L.) (Syahid \& Kristina, 2008). BAP dan TDZ merupakan jenis sitokinin yang banyak digunakan dalam kultur in vitro dengan tingkat keefektifan yang tinggi dalam memacu pertumbuhan tunas pada kisaran konsentrasi tertentu. Yadav et al. (2010) juga menambahkan bahwa perbandingan keefektifan beberapa jenis sitokinin yang diuji (TDZ, BAP, Kinetin, Zeatin, dan iP) pada kisaran konsentrasi tertentu dalam merangsang pembentukan tunas menunjukkan urutan keefektivan yaitu TDZ $>$ iP $>$ Zeatin $>$ BAP > Kinetin, dengan tingkat keefektifan tertinggi terdapat pada TDZ dan terendah pada Kinetin.

Air Kelapa merupakan salah satu sumber sitokinin alami yang dapat digunakan dalam kultur in vitro tanaman. Penggunaan air kelapa dalam kultur in vitro tanaman telah banyak dilakukan (Mohammad, 2010; Nasib et al., 2008; Michael, 2011; Kristina \& Syahid, 2012). Air kelapa memiliki beberapa kandungan nutrisi, mineral, vitamin, asam amino, gula, dan hormon. Kandungan hormon yang terdapat pada air kelapa terdiri atas hormon auksin, giberelin, sitokinin, dan difenilurea, dengan kandungan terbesar terdapat pada difenilurea (USDA, 2008). Wattimena dkk (1988) menyebutkan bahwa difenilurea yang terkandung didalam air kelapa memiliki aktivitas sama seperti sitokinin, sehingga dalam penggunaannya air kelapa mampu merangsang pembentukan tunas dengan nilai yang tinggi dan tidak berbeda nyata dengan perlakuan yang menggunakan ZPT sintetik. Hall dkk (2000) dalam Peixe dkk. (2007) menyatakan bahwa di dalam air kelapa terdapat kandungan zeatin yang cukup tinggi sehingga sangat penting untuk dipergunakan dalam mikropropagasi tanaman.

\section{Jumlah Daun per Eksplan}

Berdasarkan data analisis ragam, menunjukkan bahwa penambahan sitokinin pada media MSB5 memberikan hasil yang berbeda nyata terhadap jumlah daun rata-rata per eksplan pada 12 MST. Perlakuan yang digunakan dalam percobaan mampu merangsang pembentukan daun pada tunastunas yang terbentuk. Perlakuan terbaik terdapat pada perlakuan C (BAP 1,5 mg/l), D (BAP 2,0 mg/l), H (TDZ 0,01mg/l), I (TDZ 0,1 mg/l), dan K (Air Kelapa $10 \%$ ), sedangkan pada 12 MST perlakuan terbaik terdapat pada perlakuan B (BAP 1,0 mg/l), C (BAP 1,5 mg/l), D (BAP 2,0 mg/l),H (TDZ 0,01mg/l), I (TDZ 0,1 mg/l), dan K (Air Kelapa 10 \%) dengan nilai rata-rata yang tidak berbeda nyata. Penggunaan BAP, TDZ, dan Air Kelapa dalam kultur in vitro menunjukkan respon yang baik terhadap pembentukan daun pada eksplan yang dikulturkan. Perlakuan-perlakuan dengan hasil terbaik dalam rata-rata jumlah daun per eksplan berbanding lurus dengan hasil terbaik dalam rata-rata jumlah tunas per eksplan. Hal ini ditunjukkan oleh perlakuan $C$ (BAP 1,5 mg/l, D (BAP 2,0 mg/l), H (TDZ 0,01 mg/l), dan K (Air Kelapa 10\%), dimana keempat perlakuan ini merupakan perlakuan yang lebih baik pada peubah rata-rata jumlah tunas per eksplan.

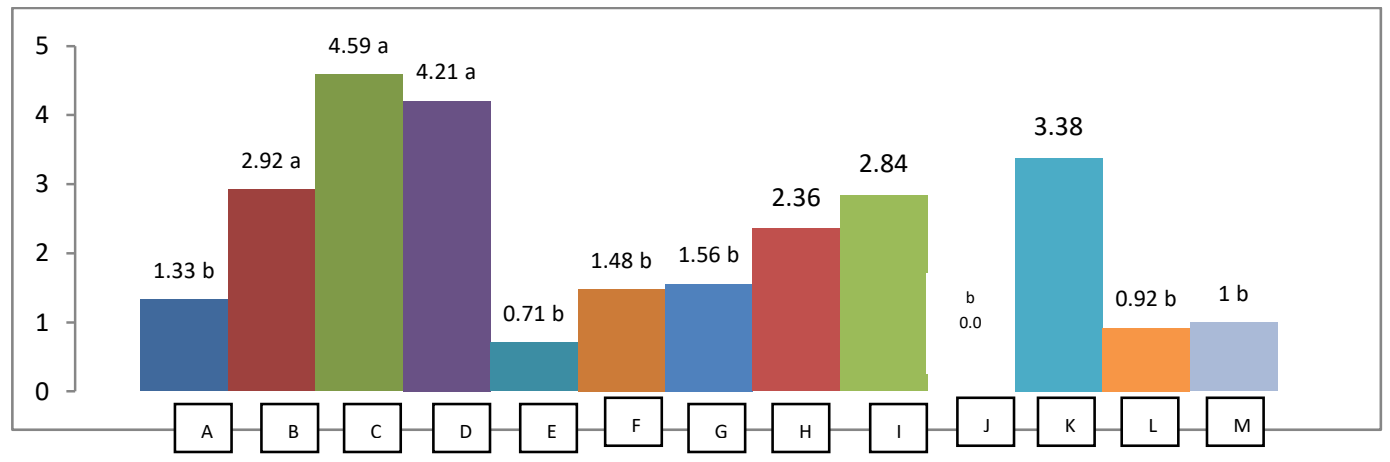

A (Tanpa ZPT (Kontrol); B (BAP 1,0 $\mathrm{mg} \mathrm{L}^{-1}$ ); C (BAP 1,5 $\mathrm{mg} \mathrm{L}^{-1}$ ); D (BAP 2,0 $\mathrm{mg} \mathrm{L}^{-1}$ ); E (Kinetin 0,5 $\mathrm{mg} \mathrm{L}^{-1}$ ); $\mathrm{F}$ (Kinetin 1,0 $\mathrm{mg} \mathrm{L}^{-1}$ ); G (Kinetin 1,5 $\mathrm{mg} \mathrm{L}^{-1}$ ); $\mathrm{H}$ (TDZ 0,01 $\mathrm{mg} \mathrm{L}^{-1}$ ); I (TDZ 0,1 $\mathrm{mg} \mathrm{L}^{-1}$ ); J (TDZ 1,0 $\mathrm{mg} \mathrm{L}^{-1}$ ); K (Air Kelapa 10\%); L (Air Kelapa 15\%); M (Air Kelapa 20\%).

Gambar 5. Data jumlah daun pada 12 MSI. 
Ketiga jenis sitokinin tersebut (BAP, TDZ, Air kelapa) mampu menstiulasi pembentukan daun pada eksplan embrionic axis kedelai var. Mutiara 1 secara in vitro. Penggunaan BAP dengan konsentrsi 1,5 $\mathrm{mg} / \mathrm{l}$ dilaporkan mampu menghasilkan jumlah daun tertinggi diantara perlakuan lainnya (Balogun, 2007). Penggunaan TDZ dalam kultur in vitro lebih ditujukan untuk pembentukan tunas adventif pada suatu kultur. Lu (1993) menyebutkan bahwa TDZ dapat merangsang pembentukan tunas adventif dan proliferasi tunas aksilar (Shankla et al., 1996). TDZ dalam kultur in vitro tanaman tidak hanya berperan dalam peningkatan pembentukan tunas, namun berperan juga dalam peningkatkan tinggi tunas dan jumlah daun per eksplan (Supriati et al., 2006).

Berdasarkan komposisi mineral dan hormon yang terkandung tersebut, maka diduga air kelapa dapat memberikan pengaruh yang baik terhadap rata-rata jumlah daun per eksplan (Gambar 5.). Amutha et al. (2003) menambahkan bahwa penggunaan air kelapa dengan kosentrasi $10 \%$ dapat merangsang pembentukan tunas pada empat varietas tanaman kacang hijau. Tunas-tunas yang terbentuk akan membentuk daun, sehingga secara tidak langsung perlakuan yang diguanakan dapat meningkatkan jumlah daun yang terbentuk. Senyawa-senyawa yang terkandung di dalam air kelapa memiliki komposisi yang kompleks baik dalam bentuk vitamin, asam amino, mineral, gula maupun hormon. Air kelapa memiliki kandungan unsur $\mathrm{K}$ tertinggi dalam komposisi mineralnya diikuti dengan natrium ( $\mathrm{Na}$ ) dan kemudian $\mathrm{Mg}$ serta diikuti oleh unsur-unsur lainnya (USDA, 2008). Proses pembentukan daun dalam kultur in vitro dengan penambahan air kelapa, berkaitan dengan keberadaan unsur $\mathrm{K}$ dan $\mathrm{Mg}$ yang relatif tinggi pada media yang digunakan.

\section{KESIMPULAN}

1. BAP $1,5 \mathrm{mg} / \mathrm{l}$ merupakan perlakuan terbaik terhadap multiplikasi eksplan embrionic axis kedelai var. Mutiara 1 secara in vitro, terutama pada peubah jumlah tunas dan jumlah daun, sedangkan persentase membentuk kalus yang relatif tinggi terdapat pada perlakuan dengan penggunaan AP 2,0 mg/ldalam pembentukan kalus.
2. Air Kelapa dapat menggantikan penggunaan sitokinin sintetik dalam merangsang multiplikasi eksplan embrionic axis kedelai var.Mutiara 1 secara in vitro.

\section{DAFTAR PUSTAKA}

Adisarwanto. 2008. Budidaya Kedelai Tropika "Upaya Peningkatan Produksi dan Produktivitas dengan Penggunaan Varietas Unggul serta Waktu dan Lokasi Penanaman yang Tepat". Penebar Swadaya. Depok.

Amutha, S, A Ganapathi, and M Muruganatham. 2003. In vitro organogenesis and plant formation in Vigna radiata (L.) Wilczek. Plant Cell, Tissue and Organ Cultur 72: 203207.

Balogun, MO, SR Akande, and BA Ogunbodede. 2007. effect of plant regulators on callus, shoot, and root fotmation in fluted pumpkin (Telfairia occidentalis). Afric. J. Biotech 6(4): 355-358.

BPS. 2013. Produksi Padi, Jagung, dan Kedelai (Angka Ramalan 1 Tahun 2013). http://www.bps.go.id/brs_file/aram_01jul13. pdf. Diakses pada 31 Januari 2014.

BPS. 2013. Tanaman Pangan. http://www.bps.go.id/tnmn_pgn.php.

Diakses pada 5 Juni 2014.

Da Silva AL, CS Caruzo, RA Moreira, and ACG Horta. 2003. In vitro induction of callus from cotyledon and hypocotyl explants of Glycine wightii (Wight \& Arn.) Verdc. Ciênc. Agrotec. Lavras. 27(6): 1277-1284.

Dinas Pertanian Tanaman Pangan Provinsi Jawa Barat. 2012. Kedelai Super Jumbo Var. Mutiara

1.http://www.diperta.jabarprov.go.id/index. php/subMenu/informasi/artikel/detailartikel /244. Diakses pada 20 Februari 2014.

George, EF, and PD Sherrington. 1984. Plant Propagation by Tissue Culture. Exegetic Ltd., Eversley. 709 p.

Gunawan, LW. 1988. Teknik Kultur Jaringan Tumbuhan. Laboratorium Kultur Jaringan Tumbuhan. PAU-IPB-Bogor.158 hal.

Guo, B, BH Abbasi, A Zeb, LL Xu, and YH Wei. 2011. Thidiazuron: a multi-dimentional plant growth regulator. Afric J. Biotech 10(45): 8984-9000.

Harsono, A. 2008. Strategi pencapaian swasembada kedelai melalui perluasan areal tanam di 
lahan kering masam. Iptek Tanaman Pangan 3 (2).

Hesar AA, B Kaviani, A Tarang and SB Zanjani. 2011. Effect of different concentration of kinetin on regeneration of ten weeks (Matthiola incana). Plant. Osm. J. 4(5): 236238.

Huda, S, R Islam, MA Bari, and M Asaduzzaman. 2003. Shoot diferentiation from cotyledon derived callus of chickpea (Cicer arietum L.). Plant Tissue Culture 13(1): 53-59.

Hutchinson, MJ, R Onamu, L Kipkosgeidan, SD Obukosia. 2010. Effect of thidiazuron, NAA and BAP on in vitro propagation of Alstroemeria aurantica cv. 'Rosita'from shoot tip explants. JAGST 12 (2) : 60-69.

Kaneda, Y, Y Tabei, S Nishimura, K Hareda, T Akihama, and K Kitamura. 1997. Combination of thidiazuron and basal media with low salt concentration increases the frequency of shoot organogenesis in soybeans (Glycine max (L.) Merr.). Plant Cell Reports 17:8-12.

Kristina, NN, dan SF Syahid. 2012. Pengaruh air kelapa terhadap multiplikasi tuna sin vitro, produksi rimpang, dan kandungan xanthorrhizol temulawak di lapangan. J. Littri 18(3): 125-134

Lestari, E. 2011. Peran zat pengatur tumbuh dalam perbanyakan tanaman melalui kultur jaringan. J. AgroBiogen 7(1): 63-68.

$\mathrm{Lu}, \mathrm{CY} .1993$. The use of thidiazuron in tissue culture in vitro cell Dev. Biol. 29:92-96.

Michael, PS. 2011. Effect of coconut water on callus initiation and plant regeneration potentials of sweetpotatos. J. Proceedings of the Royal Society of New South Wales 144(3 \& 4): 91-101.

Mok DWS and MC Mok. 2001. Cytokinin metabolism and action. Annu Rev Plant Physiol Plant Mol Biol 252:89-118.

Mohammad, S, and M Ali. 2010. Effect of coconut water on callus growth of Cyamopsis tetragonolobust. Pharmacia 1(1): 25-27.

Nasib, A. K Ali and S Khan. 2008. An optimized and improved method for the in vitro propagation of kiwifruit (Actinidiadeliciosa) using coconut water. Pak. J. Bot., 40(6): 2355-2360.

Parabia, FM, B Gami, IL Kothari, JSS Mohan, and MH Parabia. 2007. Effect of plant regulators on in vitro morphogenesis of Leptadenia reticulata (Retz.) W. \& A. from nodal exsplants. Current science, 92(9): 12901293.

Peixe, A, A Raposo, R Lourenco, H Cardoso, and E Macedo. 2007. Coconut water and BAP succesfully replaced zeatin in olive (Oleaeuro paea L.) micropropagation. Scientia Horticulture 113 (1): 1-7.

Pertamawati. 2010. Pengaruh fotosintesis terhadap pertumbuhan tanaman kentang (Solanum tuberosum L.) dalam lingkungan fotoautotrop secara in vitro. Jurnal Sains dan Teknologi Indonesia. 12 (1) : 31-37.

Pierik, RLM. 1997. In Vitro Culture of Higher Plants. Kluwer Academic Publishers, Dordrecht, The Netherlands.

Purwantoro. 2012. Percepatan Penyebaran Varietas Unggul Melalui SiStem Penangkaran Perbenihan Kedelai di Indonesia. Balai Penelitian Tanaman Aneka Kacang dan Umbi. Malang.

Radhakrisnan, R, and BD Ranjithakumari. 2007. Callus induction and plant regeneration of indian soybean (Glycine max (L.) Merr.cv.CO3) via half seed explant culture. J. Agric. Technol. 3(2): 287-297.

Rao, S, P Patil, and CP Kaviraj. 2005. Callus induction and organogenesis from various explants Vigna radiata (L.) Wilczek. Indian J.Biotech. 4 : 556-560.

Suherman, M. 2013. LIPUTAN KHUSUS: Agar Kedelai Kembali Dilirik. Tabloid Agrina.http://www.agrinaonline.com/redesign2.php?rid= 19\&aid=4264. Diakses pada 1 Maret 2013.

Sumartini. 2010. Penyakit karat pada kedelai dan cara pengendaliannya yang ramah lingkungan. Balai Penelitian Tanaman Pangan dan Kacang-kacangan, Malang. J. Litbang Pertanian, 29 (3) : 59-66.

Supriati, Y, I. Mariska, dan Mujiman. 2006. Multiplikasi tunas belimbing dewi (Averhoa carambola) melalui kultur invitro. Buletin Plasma Nutfah 12 (2): 50-55.

Syahid, SF dan NN Kristina. 2008. Multiplikasi tunas, aklimatisasi dan analisis mutu simplisia daun encok (Plumbago zeylanica L.) asal kultur in vitro periode panjang. Bul.Litro 19(2): 117-128.

USDA National Nutrient Database for Standard Reference. 2008. Nuts, coconut water (liquid from coconut). http://www.nal.usda.gov/fnic/foodcomp/cgi 
-bin/list_nut_edit.pl. Diakses pada 3 Maret 2014.

Lubaina, AS, and K Murugan. 2011. Effect of growth regulators in callus induction, plumbagin content and indirect organogenesis of Plumbago zeylanica. Int J Pharm Pharm Sci, 4(1) : 334-336.

USDA National Nutrient Database for Standard Reference. 2008. Nuts, coconut water (liquid from coconut). http://www.nal.usda.gov/fnic/foodcomp/cgi -bin/list_nut_edit.pl. Diakses pada 3 Maret 2014.

Wahyudi, BI, A Rial, dan M Shiddiq. 2012. Deskripsi Varietas Unggul Hasil Pemuliaan Mutasi. Pusat Diseminasi IPTEK Nuklir - Badan Tenaga Nuklir Nasional. Jakarta. http://dph.madiunkab.go.id/downlot.php?fil $\mathrm{e}=$ deskripsiVarietas1.pdf.Diakses pada 31 Januari 2014

Wattimena, GA. 1988. Zat Pengatur Tumbuh Tanaman. Pusat Antar Universitas Institut Pertanian Bogor. Bogor.

Yadav, SK, S Kachwaha, and SL Khotari. 2010. Comparison of in vitro regeneration efficiency of leaf explants in response to different cytokinins and assessment of genetic uniformity of regenerated plants of Solanum surattense Burm.f. African Journal of Biotechnology 9 (53): 8991-8997.

Zia, M, ZF Rizvi, R Rehman and MF Chaudhary. 2010. Micropropagation of two pakistan soybean (Glycine max L.) cultivars from cotyledonary nodes. J. Agr. R 8(2): 448-453. 